Samaira Yasmin, Shazia Nouren, Haq Nawaz Bhatti, Dure Najaf Iqbal, Shan Iftikhar, Junaid Majeed, Rahat Mustafa, Numrah Nisar, Jan Nisar, Arif Nazir*, Munawar Iqbal and Hina Rizvi

\title{
Green synthesis, characterization and photocatalytic applications of silver nanoparticles using Diospyros lotus
}

https://doi.org/10.1515/gps-2020-0010

Received March 28, 2019; accepted July 29, 2019.

Abstract: Currently, the green route for synthesis of silver nanoparticles (Ag NPs) using plants leaf extract is an emerging research area in nanotechnology. The present study was explored for synthesis, characterization and catalytic application of Ag NPs using Diospyros lotus fresh leaf extracts. Factors affecting the synthesis were optimized and optimum conditions were $\mathrm{pH}$ of 8.6, silver nitrate $\left(\mathrm{AgNO}_{3}\right)$ concentration of $1.5 \mathrm{mM}$ and $10 \mathrm{~mL}$ leaf extract. Formation of Ag NPs was observed by change in color of reaction mixture from pale yellow to reddish brown. The synthesized Ag NPs were characterized using UV-Vis spectrophotometer, EDX, XRD and SEM analyses. UV-Vis spectrophotometer showed maximum absorbance peak in the range of $407 \mathrm{~nm}$ at different time intervals indicating formation of Ag NPs. SEM and XRD analysis confirmed face centered cubic structure and crystalline nature of biologically synthesized Ag NPs with average particle size of $27 \mathrm{~nm}$. The purity of synthesized Ag NPs was revealed by EDX. Finally, photo catalytic activity (PCA) of Ag NPs was studied and $72.91 \%$ decolorization of industrial waste water was obtained at $54 \mathrm{~h}$. Some important parameters like $\mathrm{pH}$, turbidity, conductance; TSS, TDS, sulphide, sulphates, etc. were also monitored before and after treatment with Ag NPs.

\footnotetext{
* Corresponding author: Arif Nazir, Department of Chemistry, The University of Lahore, Lahore, Pakistan, email: anmalik77@gmail.com Samaira Yasmin, Department of Chemistry, Women University of Azad Jammu \& Kashmir, Bagh, Pakistan

Shazia Nouren, Department of Chemistry, Govt. College Women University, Sialkot, Pakistan

Haq Nawaz Bhatti, Department of Chemistry, University of Agriculture, Faisalabad, Faisalabad, Pakistan

Dure Najaf Iqbal, Shan Iftikhar, Junaid Majeed, Rahat Mustafa and Munawar Iqbal, Department of Chemistry, The University of Lahore, Lahore, Pakistan

Numrah Nisar, Department of Environmental Science, Lahore College for Women University, Lahore, Pakistan Jan Nisar, National Centre of Excellence in Physical Chemistry, University of Peshawar, Peshawar 25120, Pakistan

Hina Rizvi, Department of Environmental Sciences and Engineering, Government College University, Faisalabad, Pakistan
}

Keywords: Diospyros lotus; biological synthesis; silver nanoparticles; photocatalytic activity; bioremediation, UV-Vis spectroscopy

\section{Introduction}

Industrial sector has a great importance for economic development of country and for fulfilling the demands of increasing population resulting in the contamination of the aquatic systems [1-3]. The textile industries produce huge volume of waste water which shows resistance to decolorization by conventional methods [4-6]. For the purification of industrial waste water different methods have been adopted. These methods are time consuming and require specific conditions [7-9]. In order to solve such problems researcher have been moving in the direction of nanotechnologies as these techniques are rapid, ecofriendly and cost effective [10-16].

Nanotechnology is one of the most energetic research areas that encompass a number of disciplines. It deals with nano-sized materials $(1-100 \mathrm{~nm})$ exhibiting quite unique and improved properties, different from bulk material due to high surface area to volume ratio [17-21]. In the recent year's numerous metal NPs specifically Ag NPs have attracted in diverse field of nanoscience and technology [22-24]. Recently, the synthesis of Ag NPs is a vast area of research due to its unique applications like catalysis [25,26], antibacterial activities [27], bioremediation [28], sensors [29], electrical conductivity and purification of water [30]. Several physical and chemical protocols are in practice for the synthesis of Ag NPs but these approaches are potentially toxic to the environment, utilize a lot of energy, expensive and result in low yields [31]. To switch over these technical problems, biological methods have been employed using microorganisms and green plant extracts that are eco-friendly and cost effective alternatives to chemical and physical methods [32]. The main problem of using microorganism to synthesize Ag NPs is that it is a very time consuming process in comparison with plant extracts and special culture preparation and isolation techniques are required [33]. 
In recent years, the biosynthesis of NPs using plant extracts as reducing and capping agents has gained more interest. Researchers have been synthesizing Ag NPs using plant leaf extracts such as Aneva sativa [34], Actaea racemose [30], Tecomella undulate [35], Diospyros lotus [36], Diopyros kaki [22], Azadirachta indica [37] Diospyros malabarica [17], Chrysophyllum oliviforme [38], Datura stramonium [39], Euphorbia hirta [40], Corchorus olitorus, Ipomea batatas [41] and Nicotiana tobaccum [42]. The main advantages of using plant extracts for NPs synthesis are that it does not require high energy, toxic chemicals and the most importantly, the process is cheap, easily available, scaling-up, non-toxic, simple and safe.

The main objective of present work was the ecofriendly, rapid, reliable and inexpensive synthesis of Ag NPs using leaf extract of Diospyros lotus belonging to district Bagh and assessing its potential for efficient decolorization of industrial waste water. To best of our knowledge this is for the first time high altitude plant of Diospyros lotus of district Bagh Azad Kashmir area is being utilized for the biological synthesis of Ag NPs.

\section{Materials and methods}

All the chemicals (purity >98\%) used in this work were procured from Sigma-Aldrich Chemical Co., USA. Fresh leaves of plant Diospyros lotus (Figure 1) were collected from Rera Bagh Azad Kashmir fields. The waste water sample was procured from Environment Protection agency (EPA), Lahore.

Fresh leaves of Diospyros lotus were thoroughly washed 2-3 times with tap water followed by double

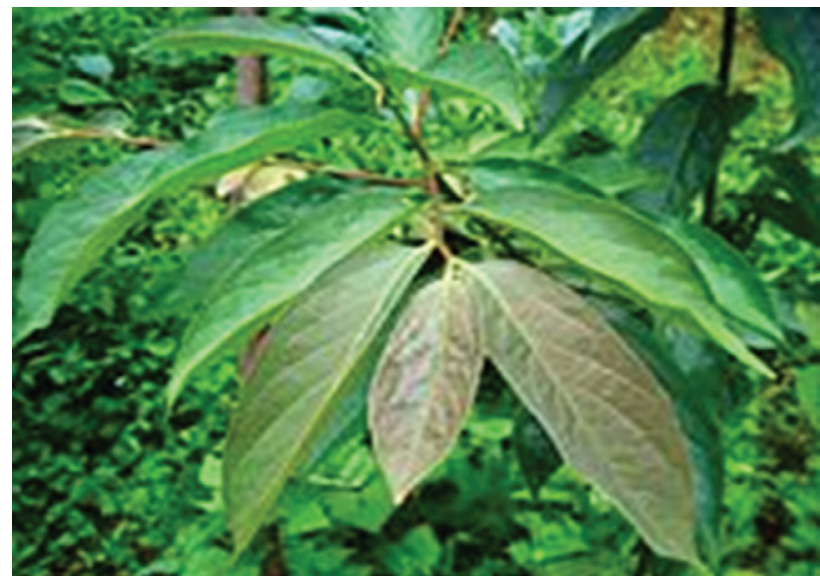

Figure 1: Pictorial representation of leaves of Diospyros lotus. distilled water to remove dust and other impurities. Leaves were weighed about $10 \mathrm{~g}$. The weighed leaves were cut into small pieces and boiled in glass beaker containing $100 \mathrm{~mL}$ distilled water for $15 \mathrm{~min}$ on hot plates. Aqueous extract was separated by filtration and stored in refrigerator at $4^{\circ} \mathrm{C}$. This filtrate was used for synthesis of Ag NPs [43].

The source of $\mathrm{Ag}$ was $\mathrm{AgNO}_{3}$ in distilled water. $90 \mathrm{~mL}$ of $1 \mathrm{mM} \mathrm{AgNO}$ solution was added in $10 \mathrm{~mL}$ leaf extract and was kept at room temperature for the reduction of $\mathrm{Ag}$ ion to Ag NPs. The NPs formation was visually identified by color change and followed by the UV-Vis spectral analysis. In order to synthesize maximum amount of Ag NPs different parameters were optimized.

\subsection{Optimization of different parameters for synthesis of Ag NPs}

The $\mathrm{pH}$ of leaf extract was varied (4.6-9.6) to study the effect on synthesis of Ag NPs. To each $10 \mathrm{~mL}$ of leaf extract having different $\mathrm{pH}, 90 \mathrm{~mL}$ of $1 \mathrm{mM} \mathrm{AgNO}_{3}$ solution was added. The $\mathrm{pH}$ of extract was adjusted by using $0.1 \mathrm{~N}$ $\mathrm{NaOH} / \mathrm{HCl}$. The concentration of $\mathrm{AgNO}_{3}$ solution was also varied from 0.1 to $2 \mathrm{mM}$ [24]. The concentration of leaf extract was also varied in the range of $5-20 \%$ by volume. Formation of Ag NPs was observed by UV-Vis spectrophotometer at different wavelength in the range of 300-700 nm [43].

\subsection{Characterization of Ag NPs}

Formation of Ag NPs was observed by UV-Vis spectrophotometer (Helios Omega, 100-240, VAC) at different wavelength (300-700 nm). Synthesized NPs were purified by repeated centrifugation at $10,000 \mathrm{rpm}$ for $20 \mathrm{~min}$. UV-Vis spectra were recorded by Helios Omega UV-spectrophotometer with respect to time. NPs were dried in oven at $45^{\circ} \mathrm{C}-50^{\circ} \mathrm{C}$. For the confirmation of crystalline size and structure of the biologically synthesized Ag NPs XRD analysis was carried out (Bruker: D8 X-ray diffractometer equipped with a $\mathrm{Cu}$ anode). $\mathrm{X}$-rays were passed through a material and the thus light diffracted at different angle. When X-ray passing through a crystal it produces a diffraction pattern, that diffraction gives the information about the atomic arrangement within the crystals. In Ag NPs, XRD gives phase structure and purity of the particle [44]. The average particle size of biological synthesized Ag NPs was calculated using Debye-Scherrer equation (Eq. 1). 


$$
D=K \lambda / \beta \cos \theta
$$

where $D$ is the crystallite size of biological synthesized Ag NPs, $\lambda$ is the wavelength of $x$-ray source $(0.1541 \mathrm{~nm})$ used in XRD, $\beta$ is the full width at half maximum of the diffraction peak, $K$ is the Scherer constant with value ranging from 0.9 to 1 and $\theta$ is the Bragg angle.

Elemental nature of the biologically synthesized Ag NPs was checked by EDX analysis (JSM-7610F). The sample X-ray energy values from the EDX spectrum were compared with known characteristic x-ray energy values to determine the presence of an element in the sample. EDX helped to verify the presence of Ag in the sample and its percentage as well. Size and shape of the biologically synthesized Ag NPs was detected using SEM analysis (JSM-5910, JEOL). It measures the electrons scattered from the sample because electrons can be accelerated by an electric potential, the wavelength can be made shorter than the one of photons. This makes the SEM capable of magnifying images up to 20,000 times. At the same time, it is possible to achieve high resolution pictures of the surface, making the instrument very useful in determining the size distribution of NPs.

Using Ag NPs as a catalyst, degradation of dyes present in industrial waste water was analyzed under sunlight. Sample of waste water was collected. Industrial waste water was 2 times diluted by double distilled water and it was scanned in the range of $350-700 \mathrm{~nm}$. $\lambda_{\max }$ was found out to be $589 \mathrm{~nm}$. About $10 \mathrm{mg}$ of biosynthesized Ag NPs were added to $100 \mathrm{~mL}$ of diluted industrial waste water. Before exposing to irradiation the suspension was well mixed by being magnetically stirred for $30 \mathrm{~min}$ to maintain equilibrium of working solution. After stirring first reading was noted then dispersion was put under sunlight and monitored from morning to evening sunset. After every one hour aliquots of 2-3 mL suspension were collected, filtered and used to evaluate the photo catalytic degradation. The concentration of dye during degradation was calculated by absorbance value measured using UV-Vis spectrophotometer at wave length $589 \mathrm{~nm}$ using formula as follows (Eq. 2):

$$
\text { Decolorization }(\%)=(\mathrm{A} 0-\mathrm{At} / \mathrm{A0}) * 100
$$

where At is the absorbance of the untreated and $A_{0}$ is absorbance of the treated effluent.

The physicochemical parameters such as colour, $\mathrm{pH}$, Chemical Oxygen Demand (COD), Total Dissolved Solids (TDS), Total Suspended Solids (TSS), turbidity, sulphides, sulphates and chlorides were estimated according to the methods prescribed in American Public Health Association (APHA) [45].

\section{Results and discussion}

Addition of plant extract of Diospyros lotus to the aqueous solution of $\mathrm{AgNO}_{3}$ led to the change in the colour of the solution from pale yellow to reddish brown indicating the reduction of $\mathrm{Ag}$ ion into $\mathrm{Ag}$ NPs due to excitation of surface Plasmon vibrations in Ag NPs [4650]. The progress of Ag NPs formation was monitored spectrophotometrically in the range of $300-700 \mathrm{~nm}$. A characteristic and well-defined absorption peak for Ag NPs was observed around $407 \mathrm{~nm}$ (Figure 2). It was observed that these NPs were more stable even for 3 weeks after their synthesis. The result obtained was similar to previous literature suggesting that the reduction of $\mathrm{Ag}$

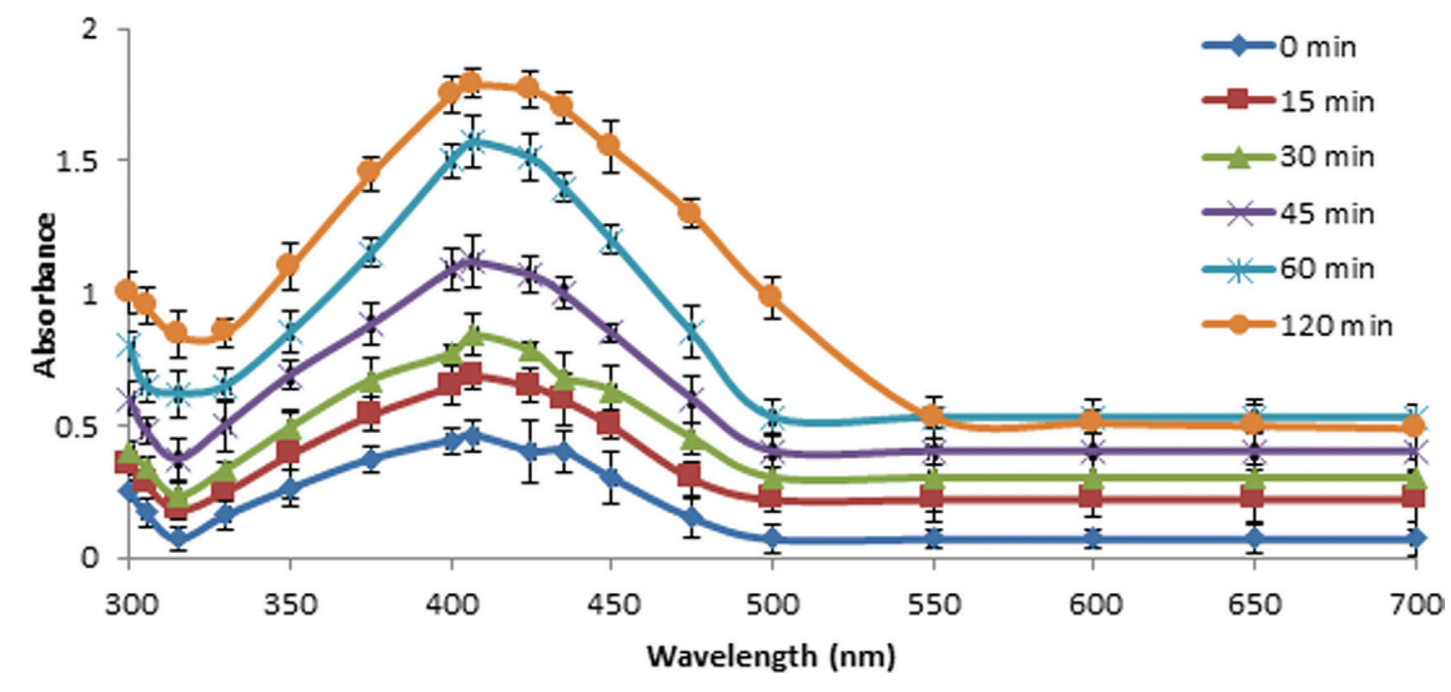

Figure 2: UV-Vis spectra of formation of Ag NPs with Diospyros lotus leaf extract. 
ion to Ag NPs was higher using the Diospyros lotus plant leaf extract. Abbasi et al. [51] synthesized Ag NPs from Allium sativum. UV-Vis spectra of dark brown colored mixture of Allium sativum extract band $\mathrm{AgNO}_{3}$ showed optimum absorbance at $400-410 \mathrm{~nm}$.

The effect of $\mathrm{pH}$ of extract on the synthesis of Ag NPs was investigated by changing the $\mathrm{pH}$ of leaf extract (4.69.6) and was characterized by colour change of reaction mixture and UV-Vis spectrophotometer (Figure 3). It was observed that the colour of reaction mixture and the intensity of the absorption peaks were $\mathrm{pH}$ dependent. When the experiment was conducted at $\mathrm{pH} 4.6$ neither color change nor clear absorption peak was observed. However, at pH 5.6 a minor absorption peak started appearing with slight change in colour after half an hour. At pH 6.6-7.6 varying shades of yellow, brown as well as reddish brown colour were observed after $10 \mathrm{~min}, 30 \mathrm{~min}$ and $1 \mathrm{~h}$, respectively. At high $\mathrm{pH}$ 8.6, dark brown colour was appeared at once with an intense absorption peak at about $407 \mathrm{~nm}$. The result revealed that the acidic $\mathrm{pH}$ suppressed the synthesis of Ag NPs due to inactive biomolecules of leaf extract. While basic $\mathrm{pH}$ was more efficient in synthesis of stabilized Ag NPs due to availability of functional groups of leaf extract.

Similar results were observed by previous literature. Amin et al. [52] synthesized Ag NPs using S. xanthocarpum berry extract $(10 \mathrm{~mL})$ in $1 \mathrm{mM} \mathrm{AgNO}$ in the $\mathrm{pH}$ ranging from 4-9 and it was investigated that acidic conditions suppressed while at higher $\mathrm{pH}$ (9.0) enhanced the synthesis of highly dispersed Ag NPs. Rashidipour and Heydari [53] prepared Ag NPs by using ( $40 \mathrm{~g} / \mathrm{L})$ oak fruit hull extract with $\mathrm{pH}$ in the range of 2-11 and $1 \mathrm{mM} \mathrm{Ag}$ nitrate solution. It was observed that rate of Ag NPs synthesis increased towards basic $\mathrm{pH}$ due to the ionization of phenolic and tannins compounds. Zia et al. [54] reported green synthesis of Ag NPs using Cydonia oblonga seeds extract at varying $\mathrm{pH}$, ranging from 3 to 11 . It was observed that at basic $\mathrm{pH}$ highly stabilized and monodispersed NPs were synthesized. Vanaja et al. [43] investigated synthesis of stabilized Ag NPs by using (10 mL) Morinda tinctoria leaf extract in $1 \mathrm{mM}$ Ag nitrate solution $(90 \mathrm{~mL})$ with $\mathrm{pH}$ ranging from 4.6-8.6. It was concluded that $\mathrm{pH} 8.6$ was found to be efficient in synthesis of Ag NPs due to availability of active functional groups. Bankar et al. [25] also reported that basic $\mathrm{pH}$ enhanced the synthesis of Ag NPs.

The concentration of $\mathrm{AgNO}_{3}$ solution also plays an important role in biological synthesis of Ag NPs which was characterized by colour change and UV-Vis spectrophotometer. At a concentration of $0.5 \mathrm{mM}$, there was no clear peak at $407 \mathrm{~nm}$ (Figure 4a) while at a concentration of $1.0 \mathrm{mM}$, the brown colour was appeared after $15 \mathrm{~min}$ of incubation, although a less intense peak was observed at $407 \mathrm{~nm}$ (Figure 4b). Moreover, it was reported that at $1.5 \mathrm{mM}$ concentration the intensity of absorption peaks increased at $407 \mathrm{~nm}$ with dark brown colour (Figure 4c). Above $1.5 \mathrm{mM} \mathrm{AgNO}_{3}$ concentration rapid conversion was observed but peak was broad (Figure 4d) which might be due to aggregation of Ag NPs. So it was concluded that $1.5 \mathrm{mM} \mathrm{AgNO}_{3}$ concentration was suitable for synthesis of NPs. These results were similar
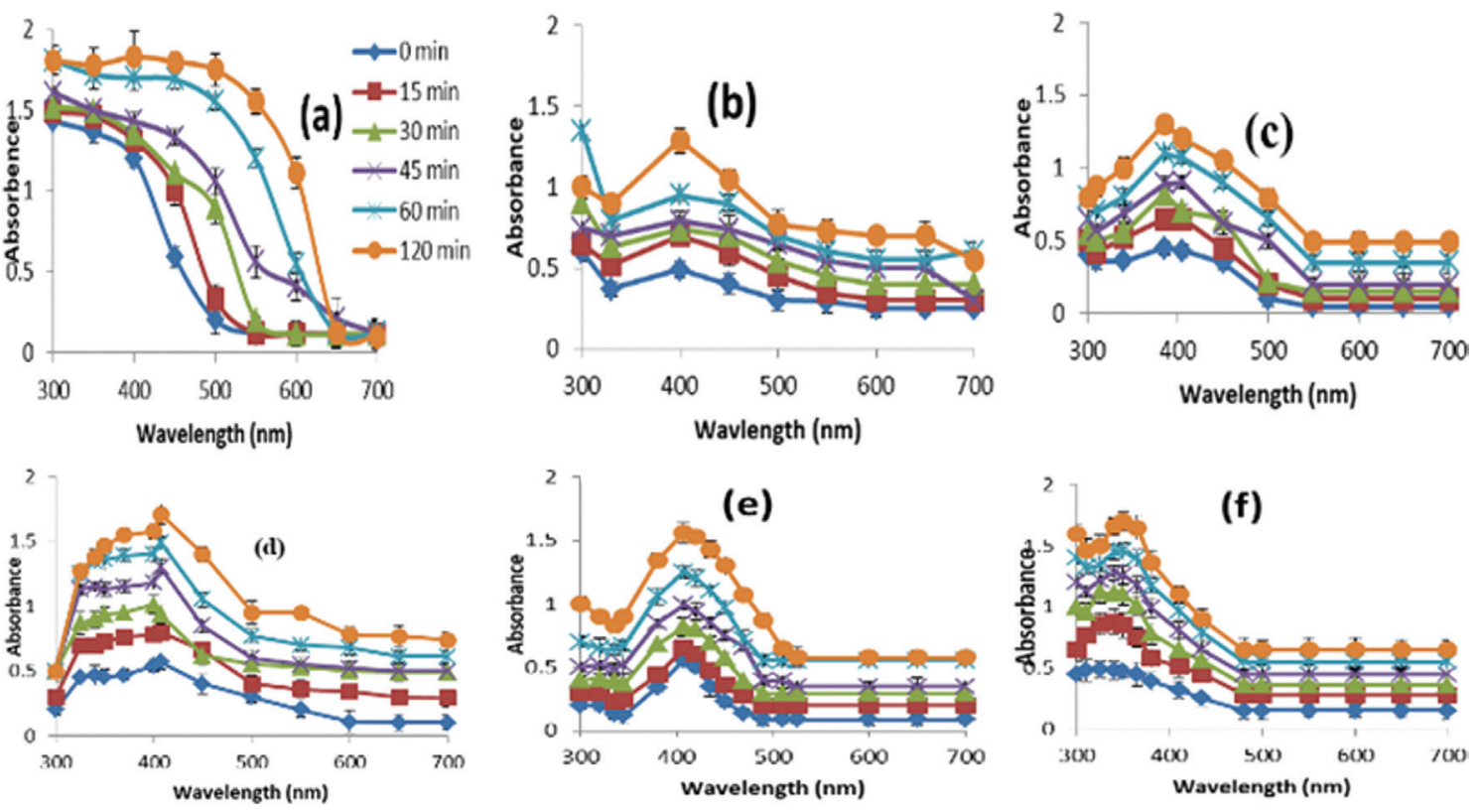

Figure 3: UV-Vis spectrum of Ag NPs synthesized by leaf extract of Diospyros lotus at different pH: (a) pH 4.6, (b) pH 5.6, (c) pH 6.6, (d) pH 7.6, (e) pH 8.6, (f) $\mathrm{pH} 9.6$ recorded at different time intervals (0-120 min). 

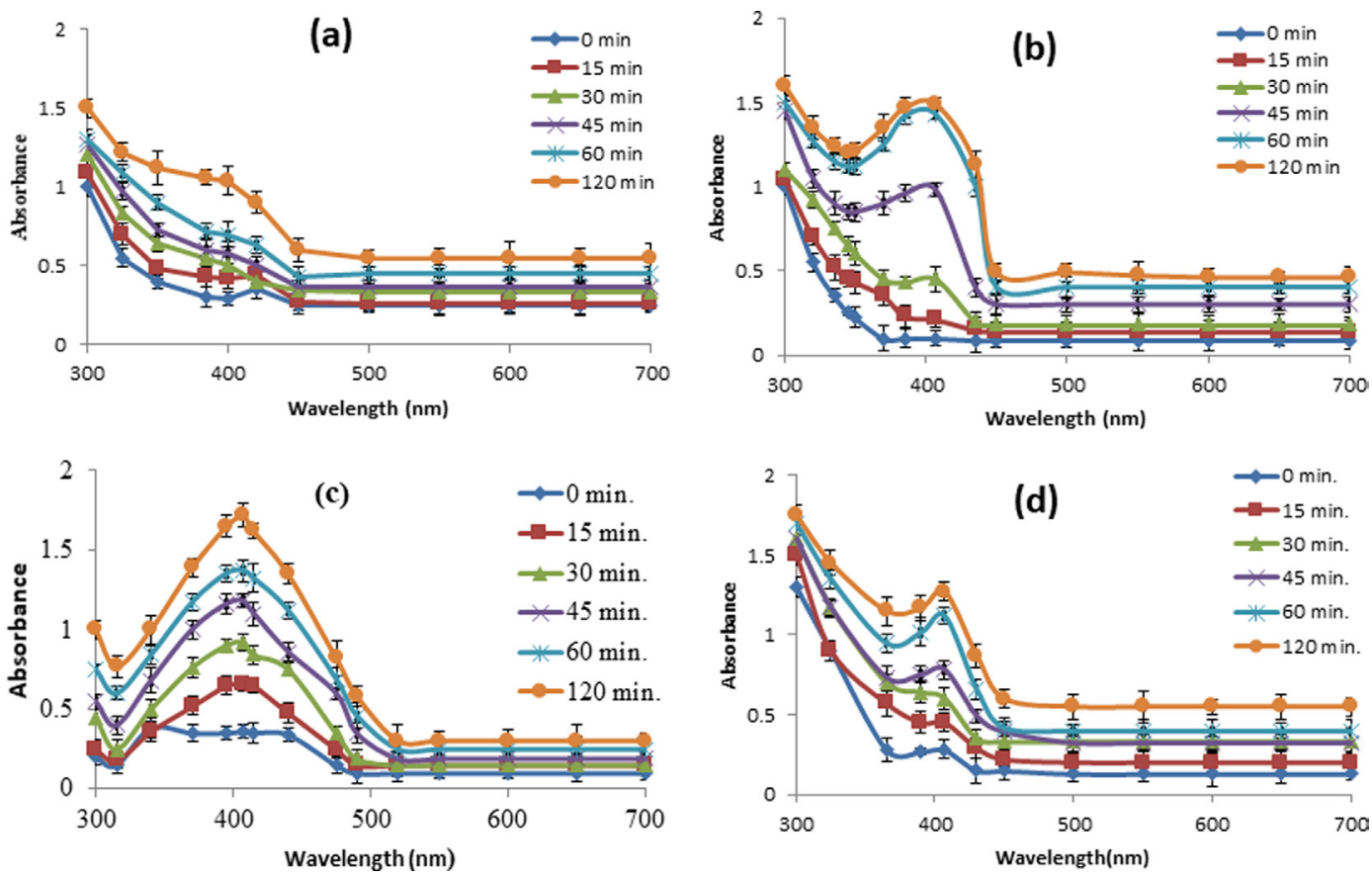

Figure 4: UV-Vis spectrum of biosynthesized Ag NPs using leaf extract of Diospyros lotus at different concentration of $\mathrm{AgNO}_{3}$ : (a) $0.5 \mathrm{mM}$, (b) $1.0 \mathrm{mM}$, (c) $1.5 \mathrm{mM}$, (d) $2.0 \mathrm{mM}$.

to those reported in previous literature. Song and Kim [24] studied the effect of various concentrations of $\mathrm{AgNO}_{3}$ (varied at $0.1-2 \mathrm{mM}$ ) with $10 \mathrm{~mL}$ of leaf extract and concluded that at higher concentrations (2 mM) stabilized Ag NPs were synthesized. Bankar et al. [25] observed the effect of varying Ag nitrate concentrations (0.125, 0.25, 0.5, 1.0, $1.25,1.50,1.75$ and $2.0 \mathrm{mM}$ ) with $10 \mathrm{~mL}$ Banana peel extract and found that optimum concentration for stabilized $\mathrm{Ag}$ NPs was higher than $1.0 \mathrm{mM}$. Pimprikar et al. [55] also synthesized Ag NPs using varying the concentration of Ag nitrate $(0.125,0.25,0.5,1.0,1.25,1.50,1.75$ or $2.0 \mathrm{mM})$. Best results were obtained at a concentration of $2 \mathrm{mM}$.

Figure 5 indicates the effect of leaf extract on the biosynthesis of Ag NPs. Ag NPs were synthesized using different concentrations of leaf extract ranging from 5-20\% with $1.5 \mathrm{mM}$ of $\mathrm{AgNO}_{3}$ solution. This effect was analyzed by UV spectrophotometer at regular time intervals $(0,30$, 60, 90 and $120 \mathrm{~min}$ ) and the colour of the solution was also observed at varying extract concentrations. With 5\% leaf extract using $1.5 \mathrm{mM}$ solution, more time was required for conversion of $\mathrm{Ag}^{+}$to $\mathrm{Ag}^{0}$ and no clear peak was observed at $407 \mathrm{~nm}$ (Figure 5a). With the 10\% leaf extract concentration, reduction occurred quickly due to the more availability of functional groups in the leaf extract. It was also observed from Figure 5b that the intensity of absorption peaks increased but peaks were somewhat broad. With increase in the concentration of the leaf extract up to $15 \%$ and $20 \%$, using $1.5 \mathrm{mM} \mathrm{AgNO}_{3}$ solution broad peak was observed at $407 \mathrm{~nm}$ which might be due to aggregation of the Ag particles due to the involvement of many more reducing agents [52,54]. These results were in close agreement to Amin et al. [52] where $10 \mathrm{~mL}$ of leaf extract concentration of Solanum xanthocarpum as was considered as optimum in the presence of $1 \mathrm{mM} \mathrm{Ag}$ nitrate solution for synthesis of stabilized Ag NPs.

The crystalline shape and size of biosynthesized Ag NPs was analyzed using X-ray diffraction pattern. XRD pattern (Figure 6) showed clear, intense and distinguishable Bragg reflections with values $77.35^{\circ}$, $64.45^{\circ}, 44.3^{\circ}$ and $38.15^{\circ}$ at $2 \theta$ that indexed to the 311,220 , 200 and 111 planes of a faced center cubic lattice of Ag. So, it was confirmed that biosynthesized Ag NPs have high degree of crystallinity and average particle size was $27 \mathrm{~nm}$ (Figure 6) calculated using Debye-Scherer equation. These $\mathrm{XRD}$ results were consistent with previous details. Bankar et al. [25] studied crystalline nature of Ag NPs using Musa paradisiacal peel extract and $1 \mathrm{mM} \mathrm{AgNO}_{3}$ solution. In the XRD pattern the diffraction peaks at (111), (200), (220) and (311) planes of a faced center cubic were obtained. Vanaja et al. [43] confirmed crystalline nature of dried Ag NPs by XRD analysis. The four distinct diffraction peaks of the $2 \theta$ values assigned to the planes were 111, 200, 220 and 311, respectively, which indicated the Ag NPs were face centered cubic and crystalline in nature.

Figure 7 shows the EDX spectrum recorded from the biologically synthesized Ag NPs showing the elemental 

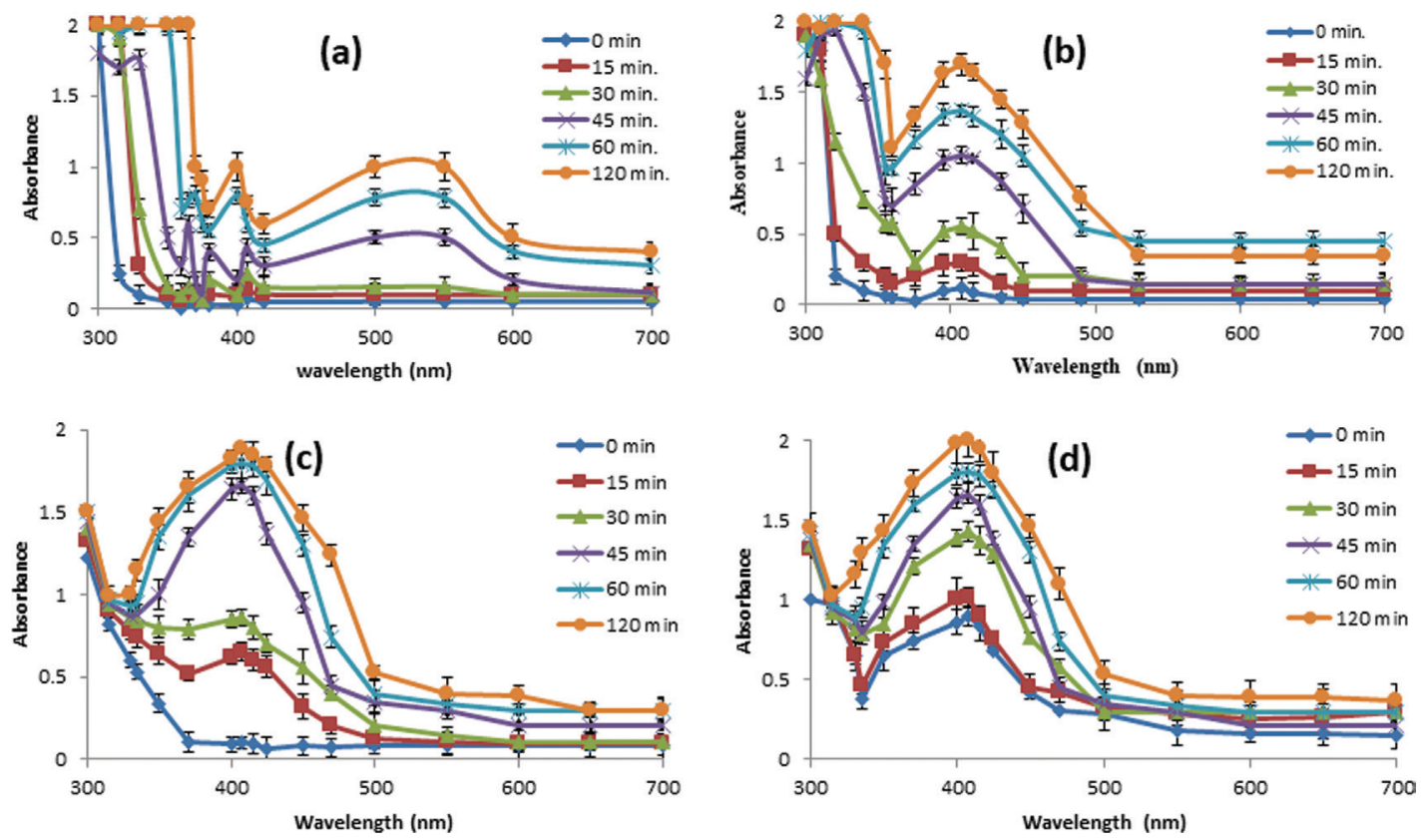

Figure 5: Ag NPs obtained with $1.5 \mathrm{mM} \mathrm{AgNO}_{3}$ against Diospyros lotus leaf extract: (a) $5 \%$, (b) $10 \%$, (c) $15 \%$, (d) $20 \%$.

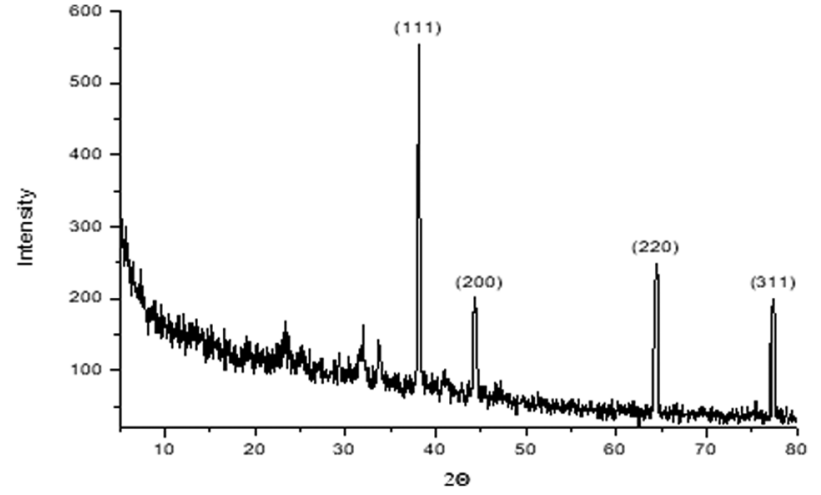

Figure 6: XRD pattern of biologically synthesized silver nanoparticles.

composition, purity and stoichiometry. A distinctive signal and high atomic percent values for $\mathrm{Ag}$ around $3.40 \mathrm{keV}$ was obtained; giving information relating to purity of biosynthesized Ag NPs. From Figure 7 it was confirmed that Ag NPs synthesized using 10\% Diospyros lotus leaf extract in $1.5 \mathrm{mM} \mathrm{Ag}$ nitrate solution at $\mathrm{pH}$ 8. A few weak signals of $\mathrm{Cl}, \mathrm{C}, \mathrm{O}, \mathrm{N}, \mathrm{Mg}$, and $\mathrm{Na}$ were also originated due to the presence of biomolecules that are bound to the surface of the Ag NPs. SEM spectrum recorded from the Ag NPs is shown in Figure 8. The SEM micrograph of biosynthesized Ag NPs showed relatively face centered cubic shaped, well distributed without aggregation and an average size of about $27 \mathrm{~nm}$ with 10\% of Diospyros lotus leaf extract in $1.5 \mathrm{mM} \mathrm{Ag}$ nitrate concentration. Ag NPs with solar light were proven very effective for decolorization of industrial waste water. PCA of biosynthesized Ag NPs was investigated

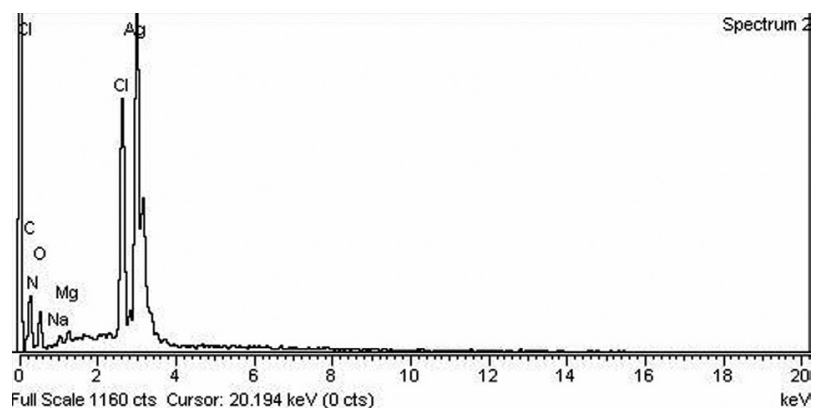

Figure 7: EDX spectrum of biologically synthesized silver nanoparticles by Diospyros lotus.

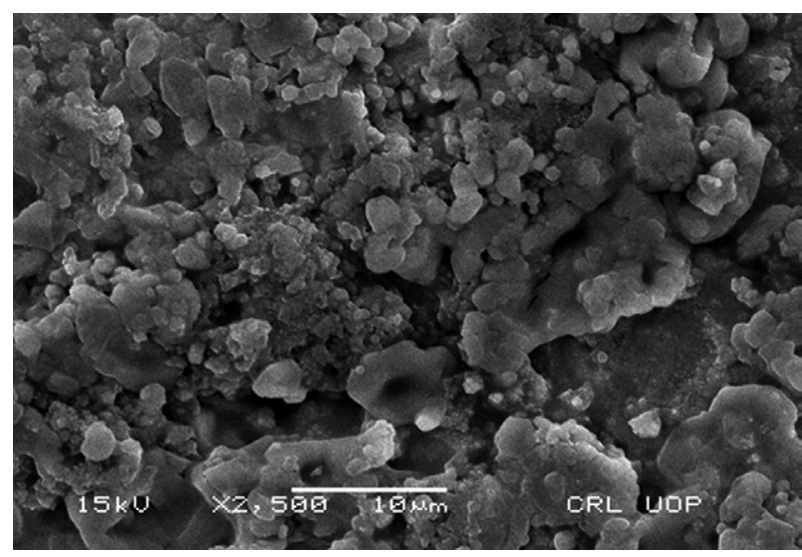

Figure 8: SEM image of biologically synthesized silver nanoparticles by Diospyros lotus leaf extract.

by decolorization of industrial waste water under solar light after different time intervals. Degradation rate was initially identified by colour change. With the passage 
of time decolorization was increased and it was observed that colour of treated industrial waste water was changed from deep blue to light blue colour after $52 \mathrm{~h}$ of exposure time. The rate of decolorization of treated industrial waste water was also observed with spectrophotometer up to $54 \mathrm{~h}$. It was observed that the absorbance of the treated waste water decreased rapidly with time. After $54 \mathrm{~h}$ of exposure time absorbance value became constant that indicated the completion of the photo catalytic degradation. The percentage of degradation efficiency of Ag NPs was calculated as $72.91 \%$ at $54 \mathrm{~h}$ (Table 1). Subsequently, physico-chemical assessment of treated waste water was also done before and after treatment with Ag NPs (Table 2). Results of each parameter were measured and compared with WHO (World Health Organization) recommended standard values, a significant variation was observed for all parameters. It was found that $10 \mathrm{mg}$ biosynthesized Ag NPs significantly affected/reduced water quality parameters. Colour, $\mathrm{pH}$ and turbidity are mainly important physical parameters to determine water quality. Before treatment colour was 1.06 TCU whereas decreased up to $0.143 \mathrm{TCU}$ after treatment. Levels of colour

Table 1: Decolorization (\%) of dyes present in industrial wastewater by biosynthesized silver nanoparticles analyzed for three days.

\begin{tabular}{lcc}
\hline Days & Exposure time (h) & Decolourization (\%) \\
\hline $1^{\text {st }}$ day & 0 & $0.30 \pm 0.987$ \\
$1 \mathrm{~h}$ & $0.53 \pm 1.693$ \\
$2 \mathrm{~h}$ & $1.05 \pm 0.47$ \\
$3 \mathrm{~h}$ & $1.95 \pm 1.765$ \\
$4 \mathrm{~h}$ & $2.10 \pm 0.0465$ \\
$5 \mathrm{~h}$ & $2.40 \pm 0.999$ \\
$6 \mathrm{~h}$ & $2.55 \pm 1.556$ \\
$7 \mathrm{~h}$ & $2.78 \pm 0.561$ \\
$8 \mathrm{~h}$ & $4.28 \pm 0.987$ \\
$9 \mathrm{~h}$ & $6.98 \pm 0.876$ \\
$10 \mathrm{~h}$ & $10.58 \pm 0.555$ \\
$24 \mathrm{~h}$ & $15.97 \pm 1.222$ \\
$2^{\text {nd }}$ day & $25 \mathrm{~h}$ & $17.85 \pm 1.350$ \\
$26 \mathrm{~h}$ & $22.13 \pm 0.657$ \\
$27 \mathrm{~h}$ & $27.16 \pm 0.587$ \\
$28 \mathrm{~h}$ & $30.53 \pm 0.876$ \\
$29 \mathrm{~h}$ & $36.23 \pm 0.342$ \\
$30 \mathrm{~h}$ & $43.06 \pm 1.999$ \\
$31 \mathrm{~h}$ & $49.66 \pm 0.099$ \\
$32 \mathrm{~h}$ & $51.76 \pm 1.0654$ \\
$34 \mathrm{~h}$ & $60.76 \pm 0.876$ \\
$49 \mathrm{~h}$ & $63.09 \pm 1.884$ \\
$50 \mathrm{~h}$ & $66.11 \pm 1.018$ \\
$51 \mathrm{~h}$ & $69.6 \pm 0.111$ \\
$3^{\text {rd }}$ day & $52 \mathrm{~h}$ & $72.86 \pm 1.987$ \\
$53 \mathrm{~h}$ & $72.89 \pm 2.00$ \\
$54 \mathrm{~h}$ & $72.91 \pm 0.998$ \\
\hline &
\end{tabular}

below 15 TCU are acceptable for drinking according to WHO (WHO 2015). This was caused by organic pollutants. Due to high surface area of biosynthesized Ag NPs, higher rate of adsorption for organic pollutants and reduction in colour of treated industrial waste water was observed. The $\mathrm{pH}$ of industrial waste water was noted in the absence and presence of biologically synthesized Ag NPs. It was found that $\mathrm{pH}$ before treatment was 9.60 whereas it decreased up to 7.35 after treatment and it was within the limit of WHO standards. According to WHO standard $\mathrm{pH}$ of drinking water lies in the range of 6.5 to 8.5 . This decrease in $\mathrm{pH}$ might be due to removal of anionic species from industrial waste water with Ag NPs. Turbidity is one of the most important operational water quality parameters. The turbidity of industrial waste water was examined before and after treatment of biologically synthesized Ag NPs. Turbidity before treatment was 44.3 NTU and after treatment it was reported to be 4.75 NTU. According to WHO standards turbidity value below 5 NTU is suitable for drinking. This value was closer to the turbidity of drinking water that is nearly equal to 5 . Turbidity of treated waste water was reduced due to removal of suspended material by good adsorption capacities of Ag NPs. It is proven that Ag NPs have an inhibitory effect towards many bacterial strains and microorganisms generally present in industrial waste water [56]. The present research reveals that the biologically synthesized Ag NPs using $10 \mathrm{~mL}$ leaf extract of Diospyros lotus also showed antibacterial activity. BOD was found to be in permissible limit (WHO 2006). This might be due attachment of $\mathrm{Ag}\left(\mathrm{Ag}^{+}\right)$ions released from biosynthesized Ag NPs which become attached to the negatively charged bacterial cell wall, rupturing it and consequently leading to disturbance of its function like bacterial respiration, outer membrane destabilization and depletion of intracellular ATP. Actually Ag has a greater affinity to react with sulphur or phosphorus-containing

Table 2: Physico-chemical assessment of waste water before and after treatment with Ag NPs.

\begin{tabular}{llcc}
\hline $\begin{array}{l}\text { Sr. } \\
\text { No. }\end{array}$ & Water quality parameters & $\begin{array}{c}\text { Before } \\
\text { treatment }\end{array}$ & $\begin{array}{c}\text { After } \\
\text { treatment }\end{array}$ \\
\hline $\mathbf{1}$ & Colour (TCU) & 1.06 & 0.143 \\
$\mathbf{2}$ & pH & 9.60 & 7.35 \\
$\mathbf{3}$ & Turbidity (NTU) & 44.3 & 4.75 \\
$\mathbf{4}$ & Biochemical oxygen demand (BOD) (mg/L) & 241 & 15 \\
$\mathbf{5}$ & Chlorides (mg/L) & 8100 & 315 \\
$\mathbf{6}$ & Sulphide (mg/L) & 06 & 1.6 \\
$\mathbf{7}$ & Sulphates (mg/L) & 165 & 13.35 \\
$\mathbf{8}$ & Total Dissolved Solids (TDS) (mg/L) & 1200 & 880 \\
$\mathbf{9}$ & Total Suspended Solids (TSS) (mg/L) & 150 & 70 \\
\hline
\end{tabular}


biomolecules of the cell like DNA and RNA and affects them badly; finally cause cell death [57].

Chlorides of industrial waste water were calculated before and after treatment with Ag NPs. Before treatment concentration of chlorides was $8,100 \mathrm{mg} / \mathrm{L}$ whereas it decreased up to $315 \mathrm{mg} / \mathrm{L}$ after treatment. Ag NPs would have adsorbed chloride ions from industrial waste water due to high surface area. The reduction in chloride ions were determined by titrimetric method. At levels above $250 \mathrm{mg} / \mathrm{L} \mathrm{Cl}$ water begins to taste salty and becomes increasingly objectionable as the concentration rises further. The present experimental data showed slight higher value. This might be due to the presence of chloride containing compounds. It was monitored that value of sulphide before treatment was $6 \mathrm{mg} / \mathrm{L}$ and after treatment it decreased to $1.6 \mathrm{mg} / \mathrm{L}$. It might be due to the reason that sulphide anion might have consumed with Ag NPs and would have formed Ag sulphide by oxidation reduction process. Industrial wastewater was evaluated for sulphates concentration before and after treatment with Ag NPs. Before treatment value of sulphates ions was $165 \mathrm{mg} / \mathrm{L}$ whereas it decreased up to $13.35 \mathrm{mg} / \mathrm{L}$ after treatment. Preferable sulphates concentration of drinking water according to WHO is $250 \mathrm{mg} / \mathrm{L}$ [58]. The reason for decrease in sulphates ion concentration might be the high adsorption capacities of Ag NPs. The TDS of industrial wastewater was also observed before and after treatment with Ag NPs. Before treatment TDS was $1,200 \mathrm{mg} / \mathrm{L}$ whereas it decreased up to $880 \mathrm{mg} / \mathrm{L}$ after treatment. It was found that reduction in size of Ag NPs increases efficiency to reduce TDS from industrial waste water and that was due to increased surface area. According to WHO (2015) TDS value of $1,000 \mathrm{mg} / \mathrm{L}$ is satisfactory for life. The TSS of industrial waste water was examined before and after treatment with biologically synthesized Ag NPs. TSS value before treatment was $150 \mathrm{mg} / \mathrm{L}$ and while it decreased up to $70 \mathrm{mg} / \mathrm{L}$ after treatment. This decrease might be due to adsorption capacities of biosynthesized Ag NPs. The acceptable range of TSS for drinking water specified by WHO was $250 \mathrm{mg} / \mathrm{L}$. After treatment with Ag NPs, all the parameters showed improvement in water quality parameters. The present study concludes that Ag NPs were effective to improve the wastewater quality.

\section{Conclusions}

The biological method for synthesis of Ag NPs using plants is very simple, fast and eco-friendly due to involvement of active molecules present in plants without using harmful chemicals. Crystalline nature with the size $27 \mathrm{~nm}$ was characterized by XRD; presence of elemental Ag was analyzed by EDX spectrum and face centered cubic structure of the NPs was assessed by SEM. The percentage of degradation efficiency of Ag NPs was calculated to be $72.91 \%$ at $54 \mathrm{~h}$. A significant variation in water quality parameters of treated waste water was observed which proves that biological Ag NPs play an important role in remediation and therefore waste water can be easily reused.

\section{References}

[1] Taricska J.R., Hung Y.-T., Li K.H., Handbook of Industrial and Hazardous Wastes Treatment. Marcel Dekker, New York, USA, 2004.

[2] Ghezali S., Mahdad-Benzerdjeb A., Ameri M., Bouyakoub A.Z., Adsorption of 2, 4, 6-trichlorophenol on bentonite modified with benzyldimethyltetradecylammonium chloride. Chem. Int., 2018, 4(1), 24-32.

[3] Abourriche A., Hannache H., Oumam M., Elaboration of novel adsorbent from Moroccan oil shale using Plackett-Burman design. Chem. Int., 2018, 4(1), 7-14.

[4] Mendhulkar D., Yadav A., Khamkar S., Photochemical decolourization of Methyl Violet dye using Azadirachta indica (Neem) mediated synthesized silver nanoparticles. Der. Pharm. Lett., 2016, 8(7), 119-128.

[5] Chikwe T.N., Ekpo R.E., Okoye I., Competitive adsorption of organic solvents using modified and unmodified calcium bentonite clay mineral. Chem. Int., 2018, 4(4), 230-239.

[6] Chidi O., Kelvin R., Surface interaction of sweet potato peels (Ipomoea batata) with $\mathrm{Cd}$ (II) and $\mathrm{Pb}$ (II) ions in aqueous medium. Chem. Int., 2018, 4(4), 221-229.

[7] Sobana N., Muruganadham M., Swaminathan M., Nano-Ag particles doped $\mathrm{TiO}_{2}$ for efficient photodegradation of direct azo dyes. J. Mol. Catal. A. Chem., 2006, 258(1-2), 124-132.

[8] Hassen E.B., Asmare A.M., Predictive performance modeling of Habesha brewery wastewater treatment plant using artificial neural networks. Chem. Int., 2019, 5(1), 87-96.

[9] Alasadi M., Khaili F.I., Awwad A.M., Adsorption of $\mathrm{Cu}(\mathrm{II})$, Ni(II) and $\mathrm{Zn}$ (II) ions by nano kaolinite: Thermodynamics and kinetics studies. Chem. Int., 2019, 5(4), 258-268.

[10] Veisi H., Razeghi S., Mohammadi P., Hemmati S., Silver nanoparticles decorated on thiol-modified magnetite nanoparticles $\left(\mathrm{Fe}_{3} \mathrm{O}_{4} / \mathrm{SiO}_{2}-\mathrm{Pr}-\mathrm{S}-\mathrm{Ag}\right)$ as a recyclable nanocatalyst for degradation of organic dyes. Mater. Sci. Eng. C., 2019, 97, 624-631.

[11] Veisi H., Ghorbani M., Hemmati S., Sonochemical in situ immobilization of Pd nanoparticles on green tea extract coated $\mathrm{Fe}_{3} \mathrm{O}_{4}$ nanoparticles: An efficient and magnetically recyclable 
nanocatalyst for synthesis of biphenyl compounds under ultrasound irradiations. Mater. Sci. Eng. C., 2019, 98, 584-593.

[12] Veisi H., Moradi S.B., Saljooqi A., Safarimehr P., Silver nanoparticle-decorated on tannic acid-modified magnetite nanoparticles $\left(\mathrm{Fe}_{3} \mathrm{O}_{4} @ \mathrm{TA} / \mathrm{Ag}\right)$ for highly active catalytic reduction of 4-nitrophenol, Rhodamine B and Methylene blue. Mater. Sci. Eng. C., 2019, 100, 445-452.

[13] Shahriary M., Veisi H., Hekmati M., Hemmati S., In situ green synthesis of Ag nanoparticles on herbal tea extract (Stachys lavandulifolia)-modified magnetic iron oxide nanoparticles as antibacterial agent and their 4-nitrophenol catalytic reduction activity. Mater. Sci. Eng. C., 2018, 90, 57-66.

[14] Banerjee P., Satapathy M., Mukhopahayay A., Das P., Leaf extract mediated green synthesis of silver nanoparticles from widely available Indian plants: synthesis, characterization, antimicrobial property and toxicity analysis. Bioresour. Bioproc., 2014, 1(1), 3-10.

[15] Bibi I., Nazar N., Iqbal M., Kamal S., Nawaz H., Nouren S., et al., Green and eco-friendly synthesis of cobalt-oxide nanoparticle: characterization and photo-catalytic activity. Adv. Powder Technol. 2017, 28(9), 2035-2043.

[16] Nazar N., Bibi I., Kamal S., Iqbal M., Nouren S., Jilani K., et al., Cu nanoparticles synthesis using biological molecule of $P$. granatum seeds extract as reducing and capping agent: Growth mechanism and photo-catalytic activity. Int. J. Biol. Macromol., 2018, 106, 1203-1210.

[17] Taranath T., Hedaginal B., Rajani P., Sindhu M., Phytosynthesis of silver nanoparticles using the leaf extract of Diospyros malabarica (desr.) Kostel and its antibacterial activity against human pathogenic gram negative Escherichia coli and Pseudomonas aeruginosa. Int. J. Pharm. Sci. Rev. Res., 2015, 30(2), 109-114.

[18] Arshad M., Qayyum A., Abbas G., Haider R., Iqbal M., Nazir A., Influence of different solvents on portrayal and photocatalytic activity of tin-doped zinc oxide nanoparticles. J. Mol. Liq., 2018, $260,272-278$.

[19] Arshad M., Qayyum A., Shar G.A., Soomro G.A., Nazir A., Munir B., et al., $\mathrm{Zn}$-doped $\mathrm{SiO}_{2}$ nanoparticles preparation and characterization undertheeffectofvarioussolvents:Antibacterial, antifungal and photocatlytic performance evaluation. J. Photoch. Photobio. B, Biol., 2018, 185, 176-183.

[20] Kausar A., Naeem K., Tariq M., Nazli Z.-I.-H., Bhatti H.N., Jubeen F., et al., Preparation and characterization of chitosan/clay composite for direct Rose FRN dye removal from aqueous media: comparison of linear and non-linear regression methods. J. Mater. Res. Technol., 2019, 8(1), 1161-1174.

[21] Igwe O., Nwamezie F., Green synthesis of iron nanoparticles using flower extract of Piliostigma thonningii and antibacterial activity evaluation. Chem. Int., 2018, 4, 60-66.

[22] Veisi H., Kazemi S., Mohammadi P., Safarimehr P., Hemmati S., Catalytic reduction of 4-nitrophenol over Ag nanoparticles immobilized on Stachys lavandulifolia extract-modified multi walled carbon nanotubes. Polyhedron, 2019, 157, 232-240.

[23] Hemmati S., Mehrazin L., Pirhayati M., Veisi H., Immobilization of palladium nanoparticles on Metformin-functionalized graphene oxide as a heterogeneous and recyclable nanocatalyst for Suzuki coupling reactions and reduction of 4-nitrophenol. Polyhedron, 2019, 158, 414-422.

[24] Song J.Y., Kim B.S., Rapid biological synthesis of silver nanoparticles using plant leaf extracts. Bioproc. Biosyst. Eng., 2009, 32(1), 79-84.

[25] Bankar A., Joshi B., Kumar A.R., Zinjarde S., Banana peel extract mediated novel route for the synthesis of silver nanoparticles. Colloid. Surf. A, 2010, 368(1-3), 58-63.

[26] Awwad A.M., Salem N.M., Aqarbeh M.M., Abdulaziz F.M., Green synthesis, characterization of silver sulfide nanoparticles and antibacterial activity evaluation. Chem. Int., 2020, 6(1), 42-48.

[27] Alzahrani E., Eco-friendly production of silver nanoparticles from peel of tangerine for degradation of dye. World J. Nano Sci. Eng., 2015, 5, 10-16.

[28] Chaudhuri S.K., Chandela S., Malodia L., Plant Mediated Green Synthesis of Silver Nanoparticles Using Tecomella undulata Leaf Extract and Their Characterization. Nano. Biomed. Eng., 2016, 8, 1-8.

[29] Ebeling A., Hartmann V., Rockman A., Armstrong A., Balza R., Erbe J., et al., Silver nanoparticle adsorption to soil and water treatment residuals and impact on zebrafish in a lab-scale constructed wetland. Comp. Water Energ. Environ. Eng., 2013, 2(03), 16-25.

[30] Zhang H., Application of silver nanoparticles in drinking water purification. University of Rhode Island, 2013.

[31] Okafor F., Janen A., Kukhtareva T., Edwards V., Curley M., Green synthesis of silver nanoparticles, their characterization, application and antibacterial activity. Int. J. Environ. Res. Pub. Health, 2013, 10(10), 5221-5238.

[32] Konishi Y., Ohno K., Saitoh N., Nomura T., Nagamine S., Hishida $\mathrm{H}$., et al., Bioreductive deposition of platinum nanoparticles on the bacterium Shewanella algae. J. Biotechnol., 2007, 128(3), 648-653.

[33] Alaraidh I.A., Ibrahim M.M., El-Gaaly G.A., Evaluation of green synthesis of Ag nanoparticles using Eruca sativa and Spinacia oleracea leaf extracts and their antimicrobial activity. Iran. J. Biotechnol. 2014, 12(1), 50-55.

[34] Amini N., Amin G., Jafari Azar Z., Green Synthesis of Silver Nanoparticles Using Avena sativa L. Extract. Nanomed. Res. J. 2017, 2(1), 57-63.

[35] Nalvothula R., Nagati V.B., Koyyati R., Merugu R., Padigya P.R.M., Biogenic synthesis of silver nanoparticles using Tectona grandis leaf extract and evaluation of their antibacterial potential. Int. J. Chem.Tech. Res., 2014, 6(1), 293-298.

[36] Rauf A., Uddin G., Siddiqui B.S., Muhammad N., Khan H., Antipyretic and antinociceptive activity of Diospyros lotus $L$. in animals. Asian Pac. J. Trop. Med., 2014, 4, S382-S386. 
[37] Ahmed S., Ahmad M., Swami B.L., Ikram S., A review on plants extract mediated synthesis of silver nanoparticles for antimicrobial applications: a green expertise. J. Adv. Res., 2016, 7(1), 17-28.

[38] Varghese R.A., Anandhi P., Arunadevi R., Boovisha A., Sounthari P., Saranya J., et al., Satin leaf (Chrysophyllum oliviforme) extract mediated green synthesis of silver nanoparticles: antioxidant and anticancer activities. J. Pharm. Sci. Res., 2015, 7(6), 266-273.

[39] Gomathi M., Rajkumar P., Prakasam A., Ravichandran K., Green synthesis of silver nanoparticles using Datura stramonium leaf extract and assessment of their antibacterial activity. ResourceEfficient Technol., 2017, 3(3), 280-284.

[40] Elumalai E., Prasad T., Kambala V., Nagajyothi P., David E., Green synthesis of silver nanoparticle using Euphorbia hirta $L$. and their antifungal activities. Arch. Appl. Sci. Res., 2010, 2(6), 76-81.

[41] Meva F.E.A., Segnou M.L., Ebongue C.O., Ntoumba A.A., Steve D.Y., Malolo F.A.E., et al., Unexplored vegetal green synthesis of silver nanoparticles: A preliminary study with Corchorus olitorus Linn and Ipomea batatas (L.) Lam. African J. Biotechnol., 2016, 15(10), 341-349.

[42] Prasad K.S., Pathak D., Patel A., Dalwadi P., Prasad R., Patel P., et al., Biogenic synthesis of silver nanoparticles using Nicotiana tobaccum leaf extract and study of their antibacterial effect. Afr. J. Biotechnol., 2011, 10(41), 8122-8130.

[43] Vanaja M., Paulkumar K., Baburaja M., Rajeshkumar S., Gnanajobitha G., Malarkodi C., et al., Degradation of methylene blue using biologically synthesized silver nanoparticles. Bioinorg. Chem. Appl., 2014, 2014, 1-8.

[44] Roy K., Sarkar C., Ghosh C., Green synthesis of silver nanoparticles using fruit extract of Malus domestica and study of its antimicrobial activity. Dig. J. Nanomater. Biostruct., 2014, 9(3), 1137-1147.

[45] Ponarulselvam S., Panneerselvam C., Murugan K., Aarthi N., Kalimuthu K., Thangamani S., Synthesis of silver nanoparticles using leaves of Catharanthus roseus Linn. G. Don and their antiplasmodial activities. Asian Pac. J. Trop. Biomed., 2012, 2(7), 574-580.

[46] Farzad E., Veisi $\mathrm{H}$., $\mathrm{Fe}_{3} \mathrm{O}_{4} / \mathrm{SiO}_{2}$ nanoparticles coated with polydopamine as a novel magnetite reductant and stabilizer sorbent for palladium ions: Synthetic application of $\mathrm{Fe}_{3} \mathrm{O}_{4} /$ $\mathrm{SiO}_{2} @ \mathrm{PDA} / \mathrm{Pd}$ for reduction of 4-nitrophenol and Suzuki reactions. J. Indus. Eng. Chem., 2018, 60, 114-124.

[47] Veisi H., Najafi S., Hemmati S., $\operatorname{Pd}(I I) / \operatorname{Pd}(0)$ anchored to magnetic nanoparticles $\left(\mathrm{Fe}_{3} \mathrm{O}_{4}\right)$ modified with biguanidine- chitosan polymer as a novel nanocatalyst for Suzuki-Miyaura coupling reactions. Int. J. Biol. Macromol., 2018, 113, 186-194.

[48] Veisi H., Safarimehr P., Hemmati S., Oxo-vanadium immobilized on polydopamine coated-magnetic nanoparticles $\left(\mathrm{Fe}_{3} \mathrm{O}_{4}\right)$ : $\mathrm{A}$ heterogeneous nanocatalyst for selective oxidation of sulfides and benzylic alcohols with $\mathrm{H}_{2} \mathrm{O}_{2}$. J. Taiwan Inst. Chem. Eng., 2018, 88, 8-17.

[49] Veisi H., Pirhayati M., Kakanejadifard A., Mohammadi P., Abdi M.R., Gholami J., et al., In Situ Green Synthesis of Pd Nanoparticles on Tannic Acid-Modified Magnetite Nanoparticles as a Green Reductant and Stabilizer Agent: Its Application as a Recyclable Nanocatalyst $\left(\mathrm{Fe}_{3} \mathrm{O}_{4} @ \mathrm{TA} / \mathrm{Pd}\right)$ for Reduction of 4-Nitrophenol and Suzuki Reactions. Chem. Select., 2018, 3(6), 1820-1826.

[50] Veerasamy R., Xin T.Z., Gunasagaran S., Xiang T.F.W., Yang E.F.C., Jeyakumar N., et al., Biosynthesis of silver nanoparticles using mangosteen leaf extract and evaluation of their antimicrobial activities. J. Saudi Chem. Soc., 2011, 15(2), 113-120.

[51] Abbasi M., Saeed F., Rafique U., Preparation of Silver Nanoparticles from Synthetic and Natural Sources: Remediation Model for PAHs. IOP Conf. Ser.-Mat. Sci., 2014, 60, 012061.

[52] Amin M., Anwar F., Janjua M.R.S.A., Iqbal M.A., Rashid U., Green synthesis of silver nanoparticles through reduction with Solanum xanthocarpum L. berry extract: characterization, antimicrobial and urease inhibitory activities against Helicobacter pylori. Int. J. Mol. Sci., 2012, 13(8), 9923-9941.

[53] Rashidipour M., Heydari R., Biosynthesis of silver nanoparticles using extract of olive leaf: synthesis and in vitro cytotoxic effect on MCF-7 cells. J. Nanostruc. Chem., 2014, 4(3), 112.

[54] Zia F., Ghafoor N., Iqbal M., Mehboob S., Green synthesis and characterization of silver nanoparticles using Cydonia oblong seed extract. Appl. Nanosci., 2016, 6(7), 1023-1029.

[55] Pimprikar P., Joshi S., Kumar A., Zinjarde S., Kulkarni S., Influence of biomass and gold salt concentration on nanoparticle synthesis by the tropical marine yeast Yarrowia lipolytica NCIM 3589. Colloid. Surf. B-Biointerfac., 2009, 74(1), 309-316.

[56] Nithya R., Ragunathan R., Decolorization of the dye congo red by pleurotus sajor caju silver nanoparticle. Int. Conf. Food Eng. Biotechnol., 2011, 2011, 12-15.

[57] Kaviya S., Santhanalakshmi J., Viswanathan B., Green synthesis of silver nanoparticles using Polyalthia longifolia leaf extract along with D-sorbitol: study of antibacterial activity. J. Nanotechnol., 2011, 2011, 1-5.

[58] Abid M., Jamil A., The assessment of drinking water quality and availability in NWFP. RWSSP, Peshawar, 2005. 